\title{
Studies on genetic variability for some metric traits in slender grain rice genotypes
}

\author{
Biswaranjan Behera ${ }^{1}$, Simanchal Sahu ${ }^{1}$, Rajesh Kumar Kar ${ }^{1 *}$ and Ritu Kumari Pandey ${ }^{2}$ \\ ${ }^{1}$ Department of Plant Breeding and Genetics, College of Agriculture Bhubaneswar, Orissa University of \\ Agriculture and Technology (Odisha), INDIA \\ ${ }^{2}$ Department of Nematology, College of Agriculture, Bhubaneswar, Orissa University of Agriculture and \\ Technology (Odisha), INDIA \\ *Corresponding author. E-mail: rajeshkar023@gmail.com
}

Received: August 19, 2017; Revised received: November 13, 2017; Accepted: February 11, 2018

\begin{abstract}
An experiment was conducted to study genetic variability in forty-nine elite slender grain rice genotypes for thirteen component characters including grain yield. The experimental materials possessed a considerable amount of variability for all the traits. Majority of the traits showed the smaller difference between phenotypic coefficient of variation (PCV) and genotypic coefficient of variation (GCV). Both PCV and GCV were high for grain yield (gm) (PCV:27.14\%, GCV:26.27\%), and fertile grains per panicles(PCV:20.61\%, GCV:20.52\%), indicating less effect of environment on these characters. PCV and GCV were moderate for characters like harvest index (PCV:16.99\%, GCV: $14.18 \%$ ), 100 seed weight (gm) (PCV:14.57\%, GCV:13.82\%), fertility percentage (PCV:15.72\%, GCV:15.05\%), flag leaf area $\left(\mathrm{cm}^{2}\right)$ (PCV:17.83\%, GCV: $17.74 \%$ ) and days to $50 \%$ flowering (PCV:11.20\%, GCV:11.17\%) indicating that there is considerable amount of environmental effect on such characters. Moderate to a high degree of heritability estimates were observed for the majority of the traits under study except for a number of effective tillers/plant indicating the low or negligible influence of environment in the expression of these traits and may respond to selection for their improvement. High heritability $\left(\mathrm{H}^{2}\right)$ estimates were associated with moderate to high genetic gain over mean (GAM) for days to 50\% flowering $\left(\mathrm{H}^{2}: 99.35 \%, \mathrm{GAM}: 19.52 \%\right)$, plant height $\left(\mathrm{H}^{2}: 93.89 \%\right.$, GAM:14.01\%), panicle length $\left(\mathrm{H}^{2}: 94.06 \%, \mathrm{GAM}: 14.04 \%\right)$, flag leaf area( $\left.\mathrm{H}^{2}: 98.93 \%, \mathrm{GAM}: 31.05 \%\right)$, fertile grains/panicle $\left(\mathrm{H}^{2}: 99.20 \%, \mathrm{GAM}: 35.98 \%\right)$, fertility percentage $\left(\mathrm{H}^{2}: 91.57 \%, \mathrm{GAM}: 25.34 \%\right), 100$ seed weight $\left(\mathrm{H}^{2}: 89.90 \%, \mathrm{GAM}: 23.06 \%\right)$ and grain yield per plant $\left(\mathrm{H}^{2}: 93.71 \%, \mathrm{GAM}: 44.76 \%\right)$ indicating the presence of additive gene effect and hence selection based on phenotypic performance for these traits would be effective.
\end{abstract}

Keywords: Genetic advance, Genetic variability, Heritability, Slender grain rice

\section{INTRODUCTION}

Rice is the staple food for two thirds of the Indian population. It accounts for about $43 \%$ of total food grain production and $46 \%$ of total cereal production in India (FAO 2015). Now-a-days emphasis has been given not only for higher yield but also for different quality traits such as texture, aroma, appearance etc. As the standard of living of people is increasing day by day people showing more interest towards slender grain for consumption due to its flavour and palatability. But most of the rice varieties are having medium bold grain. So the development of slender grain rice varieties is need of the hour. Slender grain rice varieties collected from different parts of the country will help to identify varieties suitable for cultivation in this region as well as for selecting promising varieties for use as parent material in the future breeding programme. Variability in plants is the first step in understanding how to improve or produce new plants. The characterization and varia- bility pattern of the available germplasm resources holds a promise in respect of important economic characters. The estimation of heritability has a greater role to play in determining the effectiveness of a selection of a character provided it is considered in conjunction with the predicated genetic advance. Furthermore, the progress in selection is also directly proportional to the amount of genetic gain. Therefore, the effect of selection is realized more quickly in those characters which have high heritability as well as high genetic gain. Thus genetic parameters like genotypic coefficient of variation, heritability and genetic advance are the tools in the hands of a plant breeder for ensuring efficient selection. Therefore, the current study was undertaken with the aim to study the availability of genetic variability in yield and yield attributing characters present in forty-nine elite slender grain rice genotypes.

\section{MATERIALS AND METHODS}

The experimental material used in the present investi- 
gation consisted of 14 elite slender grain rice genotypes. The test genotypes were evaluated under normal situations at Rice Research Station, Orissa University of Agriculture and Technology, Bhubaneswar during kharif 2015. Trials were laid out in a Randomized Block Design with two replications with the spacing of $15 \times 20 \mathrm{~cm}$, and the recommended cultural practices were followed including need based irrigation and plant protection to raise a normal crop. Observations were recorded on the following thirteen characters Days to $50 \%$ flowering, plant height $(\mathrm{cm})$, Panicle length $(\mathrm{cm})$,Number of effective tillers per plant, flag leaf area $\left(\mathrm{cm}^{2}\right)$,Fertile grain number, fertility percentage $(\%)$, kernel length $(\mathrm{mm})$, kernel breadth $(\mathrm{mm})$, L/B ratio , 100-seed weight (gm), harvest index, grain yield per plant $(\mathrm{gm})$ were recorded .Observations were recorded for thirteen metric traits taking five competitive plants selected randomly from middle rows of each plot; whereas, a character like days to $50 \%$ flowering was recorded on a plot basis.

The data recorded were subjected to statistical analysis based on the sample mean of the various characters under observation. The data were analysed by using ANOVA (Panse and Sukhatme, 1967) and the genetic parameters such as PCV and GCV were calculated by the formula given by (Burton ,1952), heritability broad sense $\left(\mathrm{h}^{2}\right)$ by (Burton and DeVane,1953), and genetic advance in percent of mean (genetic gain) were work out as suggested by (Johnson et al.,1955).

\section{RESULTS AND DISCUSSION}

Presence of genetic variability is a prime requirement in any crop improvement programme. The set of genotypes used in the present study indicated existence of significant differences among themselves in the characters like Days to 50\% Flowering, Plant height $(\mathrm{cm})$, Panicle length $(\mathrm{cm})$, Number of effective tillers /plant, Flag leaf area $\left(\mathrm{cm}^{2}\right)$, Fertile grain per panicle, Fertility $\%$ and Grain yield per plant(gm) as evidenced from the analysis of variance (Table 1).
The estimates of PCV and GCV indicated the existence of the considerable amount of variability of genotypes for all the characters studied. Majority of the traits showed smaller difference between PCV and GCV indicating little influence of the environment. Therefore, selection on the basis of phenotypic values for most of the characters is expected to be effective. The genotypic and phenotypic coefficient of variation in different characters maintained shows narrow differences for all the characters under study (Table 1). In general, the phenotypic coefficient of variation was higher than the genotypic coefficient of variation. In the present study highest PCV (10.85) and GCV (7.87) difference for Number of effective tillers /plant and lowest PCV (11.20) and GCV (11.17) difference for Days to $50 \%$ flowering. Higher PCV than GCV suggests the influence of environment on the expression of these characters. A similar observation has also been noted by (Fathelrahman et al., 2015), Girish, 2015). Both GCV \& PCV were high for grain yield and fertile grains per panicles suggesting that these traits are under the influence of genetic control. Also, there is less effect of environment on characters. Hence, these traits can be relied upon, and simple selection can be practiced for further improvement. Among all the characters studied, the GCV ranged from 6.55 for kernel length to 26.27 in grain yield per plant, and PCV ranged from 7.37 kernel length to 27.14 for grain yield/plant.

PCV and GCV were moderate for characters like harvest index, 100 seed weight, fertility percentage flag leaf area and days to $50 \%$ flowering indicated that there is a considerable amount of environmental effect on such characters. It also implies comparatively moderate variability and which could be exploited for improvement through selection in advance generation. Low PCV and GCV was observed for characters like plant height (PCV: 8.48, GCV:8.21), panicle length (PCV: 8.48, GCV: 8.23), number of effective tillers per plant (PCV:10.85, GCV: 7.87), kernel length(PCV: 7.37 , GCV: 6.55), kernel breadth (PCV: 9.10, GCV: 6.90) and L/B ratio (PCV: 10.39, GCV: 9.23) indicate that

Table 1. Analysis of variance for various characters (mean sum of squares) for 49 medium slender rice genotypes.

\begin{tabular}{|c|c|c|c|c|}
\hline \multirow[t]{2}{*}{ S. N. } & \multirow[t]{2}{*}{ Characters } & \multicolumn{3}{|c|}{ Mean sum of squares (df) } \\
\hline & & Replication (1) (d.f.=1) & Genotype(48) (d.f. $=48)$ & Error(d.f. $=48)$ \\
\hline 1. & Days to $50 \%$ flowering & 2.276 & $280.875^{* *}$ & 1.838 \\
\hline 2. & Plant Height (Cm) & 0.797 & $149.451 * *$ & 9.131 \\
\hline 3. & Panicle Length $(\mathrm{Cm})$ & 0.285 & $8.910 * *$ & 0.529 \\
\hline 4. & No. of effective tillers /plant & 0.850 & $3.303 * *$ & 1.564 \\
\hline 5. & Flag leaf area $\left(\mathrm{cm}^{2}\right)$ & 26.992 & $116.157 * *$ & 1.237 \\
\hline 6. & Fertile grains/ panicle & 58.939 & $1777.219^{* *}$ & 14.194 \\
\hline 7. & Fertility percentage & 35.985 & $263.487 * *$ & 22.206 \\
\hline 8. & Kernel length (mm) & 0.193 & 0.342 & 0.072 \\
\hline 9. & Kernel Breadth (mm) & 0.009 & 0.057 & 0.024 \\
\hline 10. & $\mathrm{~L} / \mathrm{B}$ ratio & 0.009 & 0.202 & 0.042 \\
\hline 11. & 100 seed wt $(\mathrm{gm})$ & 0.003 & 0.108 & 0.011 \\
\hline 12. & Harvest index & 0.004 & 0.008 & 0.003 \\
\hline 13. & Grain yield/plant (gm) & 12.864 & $26.474 * *$ & 1.664 \\
\hline
\end{tabular}

\footnotetext{
* Significant at $5 \%$ level ** Significant at $1 \%$
} 
Biswaranjan Behera et al. / J. Appl. \& Nat. Sci. 10(1): 375 - 378 (2018)

Table 2. PCV, GCV, $\mathrm{h}^{2}$ and GA estimates for various characters for 49 medium slender rice genotypes.

\begin{tabular}{llllllll}
\hline Characters & Mean & Range & $\begin{array}{l}\text { PCV } \\
(\mathbf{\%})\end{array}$ & $\begin{array}{l}\text { GCV } \\
\mathbf{( \% )}\end{array}$ & $\begin{array}{l}\text { Heritability } \\
(\mathbf{\%})\end{array}$ & $\begin{array}{l}\text { GA } \\
\mathbf{( 5 \% )}\end{array}$ & $\begin{array}{l}\text { GA over per- } \\
\text { centage mean }\end{array}$ \\
\hline Days to 50\% flowering & 105.79 & $87.50-134.00$ & 11.20 & 11.17 & 99.35 & 20.72 & 19.59 \\
Plant Height (Cm) & 101.98 & $80.20-119.80$ & 8.48 & 8.21 & 93.89 & 14.28 & 14.01 \\
Panicle Length (Cm) & 24.88 & $19.95-28.25$ & 8.48 & 8.23 & 94.06 & 3.49 & 14.04 \\
No. of effective tillers /plant & 11.84 & $8.70-14.20$ & 10.85 & 7.87 & 52.66 & 1.19 & 10.05 \\
Flag Leaf area (cm $\left.{ }^{2}\right)$ & 42.73 & $27.93-61.92$ & 17.83 & 17.74 & 98.93 & 13.27 & 31.05 \\
Fertile grains/ panicle & 144.66 & $92.80-210.50$ & 20.61 & 20.52 & 99.20 & 52.05 & $\mathbf{3 5 . 9 8}$ \\
Fertility percentage & 72.99 & $49.16-89.33$ & 15.72 & 15.05 & 91.57 & 18.50 & 25.34 \\
Kernel length (mm) & 5.61 & $4.74-6.46$ & 7.37 & $\mathbf{6 . 5 5}$ & 78.90 & 0.57 & 10.24 \\
Kernel Breadth (mm) & 1.85 & $1.37-2.32$ & 9.10 & 6.90 & 57.42 & 0.17 & 9.20 \\
L/B ratio & 3.06 & $2.26-3.80$ & 10.39 & 9.23 & 79.04 & 0.44 & 14.45 \\
100 seed weight (gm) & 1.60 & $1.10-2.16$ & 14.57 & 13.82 & 89.90 & 0.37 & 23.06 \\
Harvest index & 0.38 & $0.22-0.50$ & 16.99 & 14.18 & 69.66 & 0.08 & 20.83 \\
Grain yield/plant (gm) & 13.41 & $6.60-24.64$ & $\mathbf{2 7 . 1 4}$ & $\mathbf{2 6 . 2 7}$ & 93.71 & 6.00 & $\mathbf{4 4 . 7 6}$ \\
\hline
\end{tabular}

these characters are under high influence of environment. It also indicates narrow genetic base for these traits and improvement in these traits could be brought about by hybridization or induced mutation to widen the genetic base followed by pedigree selection in advance generation (Gangashetty et al., 2013). A review of literature from published reports on genetic variability in rice indicates very inconsistent and contrasting results by Chand et al. (2004)), Vange (2009), Ganta and Jyothula (2010), Selvaraj et al. (2011), Akhtar et al. (2011), Aditya and Bharatiya (2013), Singh et al. (2013), Ganapati et al. (2014) and Sarwar et al. (2015). However, in majority of the cases, these estimates were found to be low for days to $50 \%$ flowering and fertility percentage; moderate to low for plant height and panicle length; moderate to high for panicle number,100-grain weight and plot yield and high for number of fertile grains per panicle, harvest index and grain yield per plant. The contrasting and conflicting reports available for these two parameters for studying variability is primarily ascribed to the type of experimental materials used in various experiments. In the present study heritability (broad sense) and genetic advance as per cent of mean estimated for all the traits are presented in (Table 2).

Moderate to a high degree of heritability estimates were observed for the majority of the traits under study except for Number of effective tillers/plant indicating the low or negligible influence of environment in the expression of these traits and may respond to selection for their improvement. In rice similar results have been obtained by Raju et al. (2004), Bastia et al. (2008), Prasad et al. (2009).

The expected amount of genetic advance can be estimated by the genotypic coefficient of variation along with heritability as suggested by Burton (1952). Traits like flag leaf area, fertile grains/panicle, fertility percentage100 seed weight, harvest index, grain yield/ plant exhibited higher values of genetic advance. These results are in collaboration with the results obtained by Jaiswal et al., 2007 for a number of panicle bearing tillers, plant height, grains per panicle. Sarkar et al., 2007 for grain yield per plant, 100 grain weight, productive tillers per plant, grain per panicle, grain length, grain breadth, kernel length, panicle length and plant height and Prasad et al., 2009 for days to 50\% flowering, Number of panicle per meter row, Panicle weight, grains per panicle, test weight and grains per panicle in rice crop. The low value of genetic advance was observed for kernel breadth \& rest other traits exhibited a moderate value of genetic advance.

High to moderate heritability with low genetic gain was observed for a character like a number of effective tillers /plant, kernel length, kernel breadth, L/B ratio, 100 seed weight and harvest index. This indicates the presence of non-additive gene effect and hence selection based on phenotypic performance for these traits would be ineffective.

As genetic advance in conjunction with heritability gives a more reliable index value than heritability alone, therefore, efforts were made to indicate both heritability and genetic advance values for various traits estimated during the present investigation. High heritability estimates were associated with moderate to high genetic gain for days to $50 \%$ flowering, plant height, panicle length, flag leaf area, fertile grains/ panicle, fertility percentage, 100 - seed weight, grain yield per plant indicating the presence of additive gene effect and hence selection based on phenotypic performance for these traits would be effective. This is in accordance with the reports of Vange (2009) for days to $50 \%$ heading, days to maturity, flag leaf area, panicle weight, panicle length, number of branches/panicle, number of seeds/panicle, grain weight/panicle and seed yield. Thomas and Lal, 2012 for total tillers per plant, effective tillers per plant, filled grains per panicle, unfilled grains per panicle and yield per plant. Augustina et al. (2013 for the weight of panicle, number of grains, yield per plant. Tuwar et al. (2013) for a number of spikelets and number of grains per panicle and grain weight per panicle. Ganapati et al. (2014) for number of grains per panicle, number of tillers per plant, 1000-grain weight, L/B ratio, plant height, kernel length, grain yield per plant, kernel breadth and days to flowering and Sarwar et al., 2015 for total tillers per plant, effective tillers per plant, filled grains per panicle, unfilled grains per panicle and yield per plant in rice crop. 


\section{Conclusion}

The materials under the present piece of investigation possess a highly significant difference for all the traits, indicating the presence of substantial genetic variation and thus provide enough scope for effective selection. Both GCV and PCV were high for grain yield and fertile grains per panicles, indicating less effect of environment on characters. PCV and GCV were moderate for characters like harvest index, 100 seed weight, fertility percentage, flag leaf area and days to $50 \%$ flowering indicated that there is a considerable amount of environmental effect on such characters. Moderate to a high degree of heritability estimates were observed for the majority of the traits under study except for a number of effective tillers/plant indicating the low or negligible influence of environment in the expression of these traits and may respond to selection for their improvement. Traits like flag leaf area, fertile grains/panicle, fertility percentage, 100 seed weight, harvest index, grain yield/plant exhibited higher values of genetic advance. The low value of genetic advance was observed for kernel breadth \& rest other traits exhibited a moderate value of genetic advance. High heritability estimates were associated with moderate to high genetic gain for days to $50 \%$ flowering, plant height, panicle length, flag leaf area, fertile grains/ panicle, fertility percentage,100- seed weight, grain yield per plant indicating the presence of additive gene effect and hence selection based on phenotypic performance for these traits would be effective.

\section{REFERENCES}

Aditya, J.P and Bhartiya, A. (2013). Genetic variability, correlation and path analysis for quantitative characters in rainfed upland rice of Uttarakhand hills.Journal of Rice Research .6(2):24-34.

Akhtar, N., Nazir, M.F., Rabnawaz, A., Mahmood, T.,Safdar, M.E.,Asif, M. and Rehman, A. (2011). Estimation of heritability, correlation and path coefficient analysis in fine grain rice (Oryza sativa L.).The Journal of Animal \& Plant Sciences.2 (4):660-664.

Augustina, U.A.,Iwunor, O.P. and Ijeoma, O.P. (2013). Heritability and character correlation among some rice genotypes for yield and yield components .Journal of Plant Breeding and Genetics. 1(2):73-84.

Bastia, D., Mishra, T. K. and Das, S.R. (2008). Genetic variability and selection indices for grain yield in upland rice. Oryza, 45(1): 72-75.

Burton, G.W. (1952). Quantitative inheritance of grasses. Proc. 6th int. Grassland Congress.1: 277-283

Burton, G.W. and DeVane, E.H.(1953). Estimating heritability in tall fescue (Festuca arundinacea) from replicated clonal material. Agronomy Journal. 45: 478-481.

Chand, S. P., Roy, S. K., Mondal, G. S., Mahato, P. D., Panda, S., Sarkar, G. and Senapati, B. K.(2004). Genetic variability and character association in rainfed lowland, Aman Paddy, Environment and Ecology, 22(2):430-434

FAO (2015). Food and Agricultural organization. Online Interactive Database on Agriculture, FAOSTAT. www.fao.org.
Fathelrahman S. A., Alsadig A. I. and Dagash Y. I.(2015). Genetic variability in rice genotypes (Oryza Sativa L.) in yield and yield component under semi-arid zone (Sudan), Journal of Forest Products \& Industries, 4(2): 21-32

Ganapati, R.K., Rasul, M.G., Mian, M.A.K. and Sarkar, U. (2014).Genetic variability and character association of T -aman rice (Oryza Sativa L.).International Journal of Plant Biology \& Research, 2 (2):1013

Gangashetty, P.I., Salimath, P.M. and Hanamaratti, N.G. (2013).Genetic Variability Studies in Genetically Diverse Nonbasmati Local Aromatic Genotypes of Rice (Oryza sativa L.).Rice Genomics and Genetics, 4(2):48.

Ganta and Jyothula (2010). Genetic divergence studies in rice. International Journal of Agricultural Sciences, 6 (1): $189-192$.

Girish Chandra Tiwari (2015). Variability, heritability and genetic advance analysis for grain yield in rice. International Journal of Engineering Research and Applications, 5(7): 46-49

Jaiswal, H.K., Shrivastava, A. K. and Dey, A. (2007). Variability, correlation and path analysis for yield and quality traits in indigenous aromatic rice genotypes. Oryza, 44 (4): 395.

Johnson, H.W., Robinson, A.E. and Comstock, R.E. (1955). Estimates of genetic and environmental variability in soyabeans. Agronomy Journal. 47: 314-318.

Panse, V.G. andSukhatme, P.V. (1967). Statistical methods for agricultural workers. ICAR New Delhi. 2nd Edn. pp.381.

Prasad, R., Prasad, L. C., Agrawal, R. K. (2009). Genetic variability in traditional aromatic rice genotypes, Oryza.46 (3): 197-201.

Raju, C., Rao,M.V.B. and Sudarshanam,A. (2004). Genetic analysis and characters association in $\mathrm{F}_{2}$ generation of rice. Madras Agril.,1 (1-3): 66-69.

Sarkar, K.K, Bhutia. K.S, Senapathi, B.K and Roy, S.K. (2007). Genetic variability and character association of quality traits in rice (Oryza sativa L.). Oryza, 44(1):64-67

Sarwar, G., Hossain, M.S, Harun-ur-rashid, M., Parveem, S. (2015). Assessment of genetic variability for agromorphological important traits in aman rice, (Oryza sativa L.). International Journal of Applied Sciences and Biotechnology, 3 (1):73-79.

Selvaraj, C.I., Nagarajan, P.,Thiyagarajan, K., Bharathi, M. andRabindran, R. (2011). Genetic parameters of variability, correlation and path coefficient studies for grain yield and other yield attributes among rice blast disease resistant genotypes of rice (Oryza sativa L.). African Journal of Biotechnology, 10 (17):3322-3334.

Singh, C.M., Suresh, G., Kumar, B., Mehandi, S. (2013). Analysis of Quantitative Variation and Selection criteria for yield improvement in exotic germplasm of upland rice (Oryza sativa L.).The Bioscan., 8 (2): 485-492.

Thomas, N. and Lal, (2012). Genetic divergence in rice genotypes under irrigated conditions, Ann. Pl. Soil Res.,14 (2): 109-112.

Tuwar, A.K., Singh, S.K., Sharma, A.and P.K. Bhati, P.K. (2013). Appraisal of genetic variability for yield and its component characters in rice (Oryza sativa L.).Biolife. 1 (3):84-89.

Vange, T. (2009). Biometrical studies on genetic diversity of some upland rice (Oryza sativa L.) accessions .Nature and Science., 7(1):21-27. 